\title{
Response to Seán Manning’s Article: "Why Psychotherapy Must Be Secular”
}

\author{
Paul Solomon
}

\author{
PSychoANALYTIC Psychotherapist
}

\begin{abstract}
This article proposes that rather than being inherently dangerous, religions originate in times when people experience inter-tribal wars or other existential anxieties, and evolve in tandem with societal developments; as people become more peaceful, so do their religions. Based on Volkan's $(1985,2006$ ) analysis of psychological aspects of the conflict after 9/11 between America and some Muslims, it is suggested that religion serves as an ethnic and national identifier rather than being the source of the conflict. Jung's idea that "gods" correspond to unconscious psychic factors rather than existing as entities is cited.
\end{abstract}

\section{Waitara}

E kī ana tēnei tuhinga ehara i te ira mōrearea, engari ahu kē mai ai ngā hāhi i ngā putanga mai o ngā wheako mai i ngā riri-ā-iwi ki te iwi o ētahi atu anipānga kē atu rānei, ka putaputa haere ake i te whanaketanga hāpori; ka hūmāriē haere ake te tangata, ka pērā anō hoki ō rātau hāhi. Whakapapa atu ki tā Wākena $(1985,2006)$ tātarihanga i ètahi wāhanga mātai whaiaroaro o te taupatupatu i muri mai i 9/11 i waenga i a Ameika me ētahi Muhirama, ka puta ake te whakaaro he wāhi tuku momo tangata whakaatu iwi tangata kē te hāhi, ehara i te pūtaketanga o te riri. Ka whakahauhia ake te kī a Jung, he rite kē ngā "atua" ki ngā aranga kauwaka mauri moe kaua ki ngā kitenga kanohi.

Keywords: religion; spirituality; violence; neuroscience; neurotheology; group identity; Jung

In his article in the previous issue of Ata: Journal of Psychotherapy Aotearoa New Zealand Seán Manning (2015) argued that because religion is dangerous, psychotherapy must retain a religiously secular stance and treat the perception of a spirit world in the same way that it treats our perception of our own and others' minds and selves. I find this appealing; I grew up in an atheistic secular Jewish family, and am interested in Buddhist meditation, Taiji, and other Indigenous spiritual paths. I cannot easily imagine a religious psychotherapy. After

Solomon, P. (2016). Response to Seán Manning’s article: “Why psychotherapy must be secular”. Ata: Journal of Psychotherapy Aotearoa New Zealand, 20(1), 89-95. DOI:10.9791/ajpanz.2016.08 @ New Zealand Association of Psychotherapists Inc. 
all, our ancestor Freud was an atheist and interested in using reason (rather than belief in a spirit world) to explore how cultural and psychological symbols and myths reflect and construct human experience. Our ancestor Jung understood mythologies, dreams, gods, and transpersonal experiences as windows into his own mind and the minds of his patients. These views seem to harmonise with Seán's secular orientation to the study of human mind. So I am wondering whether a straw man is being created in the call for a secular psychotherapy. What would a religious psychotherapy look like? If there are psychotherapists who pray or karakia in sessions, perhaps that is a matter between them and their patients.

I would like to address the argument that religion is inherently violent. True that there has been much killing in the name of various religions, but false to argue that religion was the fundamental cause of the killing: to understand the causes we would need to include political, economic, and psychological factors in our analysis. This has been explored in the work of psychoanalyst Vamik Volkan (see for example his 2006 book Killing in the Name of Identity and his 1985 article "The Need to Have Enemies and Allies"). Perhaps what Seán characterised as the "unremittingly violent" (Manning, 2015, p.161) iconography of Christianity provides a container for unconscious forces that all humans share, as Volkan and Jung maintained, rather than being an essential feature of religion qua religion. I suggest that religion is not the original source of violence, but it can provide a societal container for the violence inherent in human psychology. Jung referred to a "shadow", the unconscious dark and unacceptable side of one's human personality. The shadow is un-knowable and unacceptable to the conscious personality, and is sometimes projected into others - such as those of a different religion or ethnicity - and then persecuted in the "other".

Seán Manning (2015) argued that religion in the 21st century is founded on the murderous tribal violence described in the book of Deuteronomy (approximately 700 $\mathrm{BCE}$ ), and the Koran (700 CE); and that some Christian, Jewish, and Muslim fundamentalists in the 21st century are still violent. But most other believers are not violent - Seán mentioned a loving priest in the west of Ireland - and to my mind this supports the idea that it is not the religions themselves that are violent: violence is introduced by fools, liars, rogues, and despots seeking power who cherry-pick religious texts to support political agendas; while peaceful believers select scriptural verses that place peace, love, and reciprocity at the centre of their religious practice. The relationship between religion and violence is one of correlation, not of causation.

Judaism, Christianity, and Islam began in violent times, in ethnic groups which faced threats to survival from the surrounding predatory empires of Persia, Rome, and Egypt; so these religions reflected existential anxieties. But religious and political thought can evolve and change over time. It was not until the war of American independence in the 18 th century that anyone could imagine a separation of church and state. As Karen Armstrong (2014) put it, "Until the modern period, religion permeated all aspects of life, including politics and warfare, not because ambitious churchmen had 'mixed up' two essentially distinct activities, but because people wanted to endow everything they did with significance. Every state ideology was religious" (p. 358), and many state ideologies were violent. 


\section{PAUL SOLOMON}

In the 17 th century the Pilgrim Fathers in Massachusetts at first believed all citizens of the new colony should have the same faith enforced by the government, and that the settlers had a God-given right to take the land and murder its inhabitants. This worldview began to change after the American Declaration of Independence in 1776 guaranteed freedom for religion, but also freedom from religion: an Enlightenment philosophical idea which introduced the possibility that, as Karen Armstrong (2014) said: "Freedom of thought would become a sacred value in the modern secular West, an inviolable and unnegotiable human right" (p. 247). Unfortunately this "un-negotiable human right" is often violated; to this day America and many other nations go to war "with God on our side", as Bob Dylan (1964) sang with poignant irony, and freedom of thought is swallowed up in nationalistic enthusiasm.

After the French Revolution the secularisation of the state and the curtailing of the power of the Catholic Church did not reduce violence. Karen Armstrong (2014) wrote, "No sooner had the revolutionaries rid themselves of one religion than they invented another, making the nation an embodiment of the sacred” (p. 254). Revolutionary politics became almost an object of worship, and hundreds of thousands were massacred in the reign of terror without recourse to religious rhetoric. The Napoleonic wars, the American civil war, the opium wars, World War 1, the Armenian genocide, Stalin's purges, the second world war and the Holocaust, the Ruandan and Darfur genocides - these had little or no connection with religion.

In times of conflict and threat individual identity becomes submerged in a large (nation-sized) group identity (Volkan, 2006) and the group can psychologically regress to a paranoid schizoid state. Volkan cited the example of America after 9/11: America was attacked, and President G. W. Bush split the countries of the world as either "with us or against us". America's enemies were "an axis of evil”. In the regressed state religious ideas, "America" and other markers of ethnicity became more important and criticising them was seen as traitorous. There was a surge of hatred and fear of Muslims, and the so-called "war on terror" was parsed as a clash of civilisations (Huntington, 1996) between Christendom and Muslims. This, according to Volkan, was an example of paranoid schizoid splitting rather than of religious violence per se; Christianity and Islam acted as markers of tribal and ethnic affiliation rather than being the source of the conflict. In this example too, the violence was political, and probably rooted in the deep collective unconscious.

In the 21st century we have the conflict with ISIS, the so-called Islamic state, and there have been problems in trying to talk about the relationship between Jihadism and Islam. Currently US policy is not to use the term extremist or radical or violent to modify Islam ("religion of peace"); i.e. ISIS is not Islamic. And, it is argued, we should not make any connections between the behaviour of violent extremists who claim to follow Islam and the vast majority of Muslims who do not approve of their deeds and consider them unIslamic. Seán Manning (2015) contrasted the loving priest in the west of Ireland with fundamentalist Christian fanatics who would like to execute adulterers and abortionists. I suggest that the problem of societal violence is not solved by a sweeping dismissal of all religion, but rather by dealing with individual people and groups with their differences: some people live their religion peacefully, and some want to compel others to accept their beliefs. Richard Landes (2016) described a style of living one's religion that he called 
"triumphalist religiosity". This requires dominating non-believers. Many religions in their early days reflected this ethos, and believers asserted their dominance as a visible sign of superiority, a proof of God's favour. However, in the 21st century democratic societies such behaviour is out of place.

Seán Manning (2015) brought evidence from neuroscience supporting the view that it is a feature of the way the brain interprets sensory data that has us invent gods and demons to attempt to control our existential anxiety in a capricious and unpredictable world. A neuro-psychologist to whom I sent Seán's engaging and thoughtful paper confirmed that the neuroscience was addressed in a scholarly and accurate fashion, but I would like to comment on the idea of belief in gods and demons. In the 2oth and 21st centuries many theologians from various religions (and some philosophers) encouraged humanity to move beyond conceptions of a personal or personalised “God”. For example the Christian theologian Paul Tillich (1886-1965) thought that the modern belief in an easily-understood God was an idolatry that human beings must leave behind:

The concept of a "Personal God", interfering in natural events, or being "an independent cause of natural events", makes God a natural object beside others, a being among beings, maybe the highest but nevertheless, $a$ being. This indeed is not only the destruction of the physical system but even more the destruction of any meaningful idea of God. (As cited in Armstrong, 2009, p. 269)

The sort of belief advocated by Tillich seems not to require belief in a spirit world, but creates a space for the sense of awe at the mysteries of life that Seán Manning (2015) seemed to be advocating. Perhaps Tillich's style of religious belief can co-exist with a secular psychotherapy. It seems also to harmonise with Bion's concept of "O”. According to Caper (1998), "Bion is committed to the view that there is an absolute truth which can never be known directly" ( $p$. 419). Bion (1970) wrote, “The religious mystics have probably approximated most closely to expression of experience of it" (p.30). Caper elaborated by quoting a conversation he once had with Bion:

I do not believe that when Bion wrote of the infinite he meant the Infinite. I think he was expressing his appreciation of his own ignorance. He once told me that his concept of the infinite was the extent of what he didn't know. It is unknowable not because it is ineffable, but because there is not enough time in one life to know everything, or even enough time to know all there is to know about any one thing. (Caper, 1998, p. 419)

The German philosopher Martin Heidegger wanted to dismantle the idea of God to enable us to recover a sense of Being, and thus also to achieve "the return of the holy", by eschewing calculative thinking and cultivating meditative thinking. Those who were able to achieve meditative thinking would experience an ekstasis (the Greek word meaning trance-like amazement), an experience of the world without the blinkers of goal-oriented, calculative thinking. I understand this to imply that ordinary human life is holy if we can only open our eyes and see. 


\section{PAUL SOLOMON}

In most cultures individuals report experiences that they consider "spiritual" or "mystical" when everyday reality seems suspended, any sense of individual existence evaporates, and they "see things as they really are". People experience spiritual awe, oneness with the universe, and other altered states of consciousness. Neuroscientists have investigated these phenomena, and studies (for example, see Aquili \& Newberg, 1998) use the neologism "neurotheology" to describe the scientific study of the neural correlates of religious experience.

Studies of, for example, meditating Tibetan monks, have demonstrated that spiritual experiences reflect real biologically-based events in the brain. But as Newberg said in an interview with Newsweek:

It's no safer to say that spiritual urges and sensations are caused by brain activity than it is to say that the neurological changes through which we experience the pleasure of eating an apple cause the apple to exist ... There is no way to determine whether the neurological changes associated with spiritual experience mean that the brain is causing those experiences, or is instead perceiving a spiritual reality. (Begley, 2001)

In other words, some neuroscientists claim that a spirit world is illusory, a mere function of the way the brain works, while other neuroscientists assert that the case is not proven. We cannot be certain, intellectually.

We know that there is a world of subjective experience, intuition, and emotion; it is the area where psychotherapy happens. This includes non-ordinary states where we feel we have transcended the usual boundaries of the individual self and entered an altered state of expanded awareness where we feel at one with the whole universe. There may be feelings of deep non-intellectual communion. We can feel transported by music, dance, ritual, meditation, or prayer. According to Karen Armstrong (2009), achieving such states of ekstasis, in the sense of standing outside the usual boundaries of the self, was the original purpose of most religions and did not require belief in a God or spiritual being. We term these states transpersonal, or spiritual, or shamanistic, or ecstatic. Neuroscientists have identified which areas of the brain and groups of neurons are switched on or off during these episodes, but scientific study of experience can only go so far. According to D'Aquili and Newberg (1998), the brain produces two versions of reality:

One version is a world of discrete beings, usually base-line reality, and the other version is Absolute Unitary Being, usually experienced as God. Both perceptions are accompanied by a profound subjective certainty of their objective reality.(p.15)

As a psychotherapist I want to work with patients in a way that welcomes both versions of reality. This does not require my approach to be religious in the sense of belief in a spirit world. It does, however, require me to be open to dimensions of experience that are sometimes called spiritual in my patients and in myself. As Seán Manning (2015) said, our everyday experience of being conscious in a mysterious universe is miraculous. However, we know that it is relatively easy for us to be conscious of the contents of our minds, our thoughts. Thought, reason, and science are powers of the psyche, personified in the god Apollo, of whom Shelley (1824) wrote in his "Hymn of Apollo": "I am the eye with which the 
Universe beholds itself, and knows it is divine”. But we are more than our rational minds, and to be trapped in mere rationality would be deathly. Another power of our psyche is personified in the spirit of Dionysus, god of passions, who arrives from somewhere uncivilised, symbolising everything chaotic, dangerous, and outside human reason, bringing his wine, music, and ecstasy. Psychotherapists need both Apollo and Dionysus, reason and passion. And we also need many other "gods," each one personifying a psychic state that is not easily accessible to conscious ego-based thought. Immediately after World War 2, in his article "After the Catastrophe" Jung (1945/1964) put it like this:

No one will deny the important role which the powers of the human psyche, personified as "gods", played in the past. The mere act of enlightenment may have destroyed the spirits of nature, but not the psychic factors that correspond to them. The demons have not really disappeared but have merely taken on another form: they have become unconscious psychic factors. (As cited in Tacey, 2011, p. 174)

I think if we accept the idea that we may be influenced by unconscious psychic factors we are on the road to greater self-understanding and self-responsibility. That view does not require us to believe in or worship any external gods or God, or believe in a spirit world: in that sense it is a secular understanding of life, and it does not preclude a feeling of reverence and awe in the face of the many mysteries of the experience of being human.

\section{References}

Armstrong, K. (2009). The case for God. London, UK: Bodley Head.

Armstrong, K. (2014). Fields of blood. London, UK: Vintage.

Begley, S. (2001, May 6). Religion and the brain. Newsweek. Retrieved from: http://www.newsweek. com/religion-and-brain-152895

Bion, W. R. (1970). Attention and interpretation. London, UK: Tavistock.

Caper, R. (1998). The clinical thinking of Wilfred Bion. By Joan and Neville Symington. [Review]. International Journal of Psycho-Analysis, 79, 417-420

D’Aquili, E. G. \& Newberg, A. B. (1998). The neuropsychological basis of religions, or why God won't go away. Zygon, 33(2).

Dylan, B. (1964). "With God on our side". The times they are a-changing. Columbia Records.

Fine, J. (2015). Political violence in Judaism, Christianity and Islam. Lanham, MD: Rowman and Littlefield.

Huntington, S. P. (1996). The clash of civilizations and the remaking of world order. New York, NY: Simon and Schuster.

Jung, C. G. (1964). The collected works, Vol. 10: Civilisation in transition (R. F. C. Hull, Ed. \& Trans.). New Haven, CT: Yale University Press. (Original work published 1945)

Landes, R. (2016). Triumphalist religiosity: The unanticipated problem of the 2oth century. Retrieved from http://www.tabletmag.com/jewish-news-and-politics/197151/triumphalist-religiosity.

Manning, S. (2015). On why psychotherapy must be a secular discipline. Ata: Journal of Psychotherapy Aotearoa New Zealand, 19(2),159-172. doi:10.9791/ajpanz.2015.15

Newberg, A. B., D'Aquili, E. G., \& Rause, V. (2002). Why God won't go away: Brain science and the 


\section{PAUL SOLOMON}

biology of belief. New York, NY: Ballantine Books.

Shelley, P. B. (1824). Hymn of Apollo. Retrieved from http://encyclopedia2.thefreedictionary.com/

Percy+Bysshe+Shelley

Tacey, D. (2011). Gods and diseases. Sydney, Australia: Harper Collins.

Volkan, V. (2006). Killing in the name of identity: A study of bloody conflicts. Charlottesville, VA:

Pitchstone.

Volkan, V.D. (1985). The need to have enemies and allies: A developmental approach. Political Psychology, 6(2), 219-247.

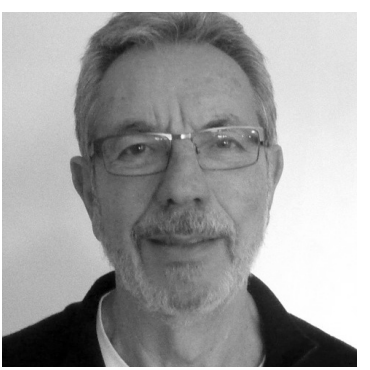

Paul Solomon is a lecturer in the discipline of psychotherapy at Auckland University of Technology and practices privately as a psychoanalytic psychotherapist. Contact details: psolomon@ aut.ac.nz . 